\title{
BENTUK ZIKIR DAN FUNGSINYA DALAM KEHIDUPAN SEORANG MUSLIM
}

\author{
Muniruddin \\ Dosen Fakultas Dakwah dan Komunikasi UIN Sumatera Utara
}

\begin{abstract}
Abstrak
Allah SWT telah menciptakan manusia sebaik-baik makhluk ciptaanNya yang dilengkapi dengan panca indera, namun sejauh mana manusia itu mampu memahami fungsi indrawi potensial kekhalifahan dalam mengemban bentuk yang paling baik (ahsani taqwim) dalam menjalani hidup dan kehidupan sehari-hariyang harus seimbang antara pemikiran dan zikir secara mahdhoh terhadap Ilahi. Karena jika tidak ada pikir dan zikir atau salah satu tidak ada, maka hidup seseorang akan mengalami kegoncangan yang dahsyat serta pada gilirannya akan terpleset jatuh yang sangat menyakitkan. Zikir merupakan kata kunci dalam sebutan lidah secara kontiniu dan i'tiqad yang tidak putus di dalam hati serta direalisasikan dalam bentuk praktek hidup dan kehidupan.
\end{abstract}

Kata Kunci: Hati, hidup, zikir

\section{A. Pendahuluan}

Zikir sebagai media untuk taqarrub (mendekatkan diri) kepada Allah.Selain itu ia juga merupakan bagian dari bentuk do'a yang dilakukan dengan penuh tadharru', khusyu' dan penuh rendah diri dihadapan Allah SWT yang dianggap sebagai bentuk zikir. Oleh sebab itu zikir dan do'a merupakan dua hal yang selamanya tidak akan pernah dapat terpisahkan, zikir dan do'a merupakan dua mata uang yang antara satu sisi dengan sisi lainnya memiliki harga yang tak ternilai.

Rasulullah SAW dalam ragam hadisnya telah bersabda bahwa dalam sebuah hadis qudsiNya Allah SWT berfirman : Barangsiapa dirinya disibukkan oleh al Qur'an untuk mengingat Aku dan tanda-tanda kebesaranKu niscaya Aku berikan kepadanya sesuatu yang lebih utama daripada apa yang Aku berikan kepada orang-orang yang bermohon kepadaKu.

\section{B. Pengertian Zikir}

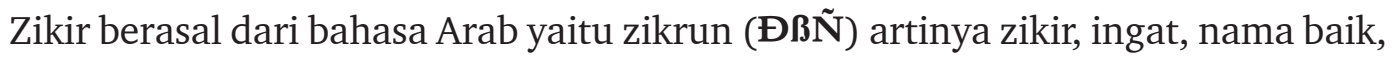

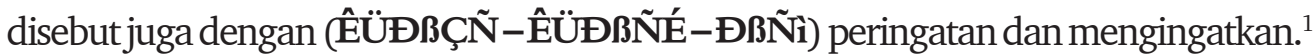

\footnotetext{
${ }^{1}$ Mahmud Yunus, Kamus Arab Indonesia, (Jakarta: Hida Karya Agung, 1990), h. 134
} 
Seperti dalam al Qur'an dinyatakan :

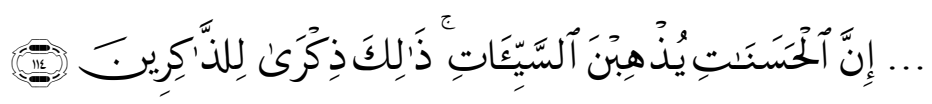

Artinya : “... Sesungguhnya perbuatan-perbuatan yang baik itu menghapuskan (dosa) perbuatanperbuatan yang buruk.Itulah peringatan bagi orang-orangyang ingat”. (QS. Hud 114)

\section{Pembagian Zikir}

Zikir dapat dibagi kepada tiga bagian, yaitu :

1. Zikru bil lisan, yaitu sebuah bentuk zikir yang realisasi pelaksanaanya dilakukan dengan cara melafazkan kalimat-kalimat tauhid, seperti tahlil, tahmid, tasbih dan lain-lain. Zikir dengan lisan ialah menyebut Allah dengan berhuruf dan bersuara. Imam Fakhrurrozi mengatakan bahwa yang dimaksud dengan zikir lisan ialah mengucapkan kalimat suci dengan lidah seperti mengucapkan tasbih Subhanallah, al hamdulillah, la ilaha illallah, Allahu akbar.

2. Zikru bil Qolb, yaitu sebuah bentuk zikir yang dilaksanakan dengan media bertafakkur, merenungkan tanda-tanda kebesaran Allah dan rahasia-rahasia Ilahiah yang tersirat melalui ciptaanNya. Zikir secara qolbi ialah mengingat atau menyebut Allah dalam hati, tidak berhuruf dan tidak bersuara, seperti tafakkur mengingat Allah, merenungi rahasia ciptaanNya secara mandalam dan merenungi tentang zat dan sifat Allah Yang Maha Mulia.

3. Zikru bil Jawarih, yaitu bentuk zikir yang direalisasikan dengan cara mengerahkan segala kekuatan dan kemampuan yang terdapat dalam jasmani sebagai manifestasi dari bentuk menaati seluruh perintah Allah dan berusaha semaksimal mungkin dalam rangka menjauhi larangan-laranganNya. ${ }^{2}$

Sabda Rasulullah SAW:

$$
\text { لا يقبل الله من عبد عملا حتى يشهد قلبه مع بدنه }
$$

Artinya : "Sesungguhnya Allah tidak akan mengabulkan amal seorang hamba hingga hati dan tubuhnya ikut berasaksi". (HR. Tirmizi)

Syeikh Abu Hasan As Sazali menyatakan: sebesar zarrah amal hati adalah seimbang dengan sebesar gunung amal anggota badan. Jika zikir dengan lidah diperkuat dengan zikir dalam hati, maka hal itu lebih sempurna, dan jika diperkuat lagi dengan menghadirkan

2 Aliyah Abidin, al Luju' Ila Allah Ad'iyyatun Wa Azkarun Min Al Qur'an Wa Assunnah, Terj. Abdurrahman Wahyudi,Mengungkap Dimensi Ibadah Zikir dan Do'a Berdasarkan al Qur'an dan Sunnah, (Semarang: Pustaka Nuun, 2009), h. 2 
pengertiannya dengan jawarih, maka hal itu lebih sempurna lagi, jika berharap kepada Allah itu dilakukan dengan sepenuh hati dan ikhlas, maka itulah puncak zikir yang paling tinggi.

\section{Bentuk-bentuk zikir bil Lisan}

\section{Zikir Tahlil}

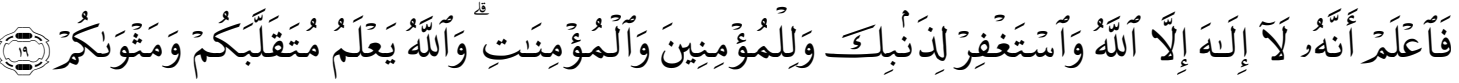

Artinya: "Maka Ketahuilah, bahwa Sesungguhnya tidak ada Tuhan (sesembahan, Tuhan) selain Allah, dan mohonlah ampunan bagi dosamu dan bagi (dosa) orang-orang mukmin, laki-laki dan perempuan. dan Allah mengetahui tempat kamu berusaha dan tempat kamu tinggal”. (QS. Muhammad 19)

Dari Jabir ra, berkata ia, bahwa Nabi SAW telah bersabda:Afdoluzzikri lailaha illallah, wa afdholuddu'a alhamdulillah. HR. Turmuzi dan an Nasa i. ${ }^{3}$

Sabda Rasulullah SAW : Barangsiapa yang mengucapkan La ialaha illallah, dengan ikhlas, maka ia masuk syurga. Ditanyakan bagaimana maksud dengan ikhlas..? Rasul menjawab: yaitu menjadi penghalangmu dari berbuat yang diharamkan Allah. HR. Thabrani, dalam format yang lain pada kitab al Ausath dan al Kabir, Rasul menjawab arti dengan ikhlas ialah ucapan la ilaha illallah mencegahmu dari apa yang diharamkan oleh Allah. ${ }^{4}$

\section{Zikir Tasbih}

Dari Sa'id bin Abi Waqash ra, ia brkata: "Kami berada bersama Rasulullah SAW, ketika beliau bersabda: apakah salah seorng dari kalian merasa tidak mampu untuk memperoleh seribu kebaikan setiap hari? Maka salah seorang dari orang yang ikut duduk bertanya: bagaimana caranya kami bisa memperoleh 1000 kebaikan ya Rasul? Rasul menjawab : bertasbihlah 100 kali, maka akan ditulis baginya seirbu kebaikan, atau dihapus darinya seribu dosa". (HR. Muslim)

Pada hadis lain menyebutkan:

$$
\text { تكتب الف حسنة وتحط عنه الف سيئة }
$$

Artinya: "Ditulis baginya 1000 kebaikan dan dihapus darinya 1000 kejelekan". (HR. Ahmad)

\footnotetext{
${ }^{3}$ Ahmad bin Hajar al Haitami, Irsyad al Ibad fi Sabili ar Rasyad, Terj. Salim Bahreisj, (Surabaya: Darussaggaf, PP. Alawy, tt.), h. 12

${ }^{4}$ Thaha Abdullah Afifi, Isyrina Miah Miftahul Jannah, 120 Kunci Surga, (Jakarta: Gema Insani Press, 1994), h. 208
} 


$$
\text { من قال: سبحان الله العظيم وبحمده غرست له نخلة في الجنة }
$$

Artinya : "Siapa yang mengucapkan Subhanallahil 'azim wa bihamdih, akan ditanamkan baginya pohon kurma di dalam surga". (HR. Tirmizi)

$$
\text { احب الكلام الى الله اربع : سبحان الله و الحمد لله ولا اله الاالله والله اكبر }
$$

Artinya : "Ucapan yang paling disukai Allah ada empat, yaitu: Subhanallah, wal hamdulillah, wala ilaha illallah wallahu akbar". (HR. Muslim) ${ }^{5}$

$$
\text { سبحان الله والحمد لله و لا اله الاالله والله اكبر احب الي مما طلعت عليه الشمس. }
$$

Artinya : "Aku mengucapkan subhanallah, al hamdulillah, lailaha illallah wal llahu akbar, lebih aku sukai dari hari yang terbit padanya matahari”. (HR. Muslim)

$$
\text { كلمتان خفيفتان على اللسان, ثقيلتان في الميز ان, حبيبتان الم الرحمان : سبحان الله بحمده سبحان }
$$

Artinya : "Dua kalimat yang ringat diucapkan lidah berat pahala ditimbang, disukai oleh Allah, itulah kalimat subhanallahi wabihamdihi subhanallahil'azim”. (HR. Bukhari \& Muslim)

\section{Zikir Sholawat}

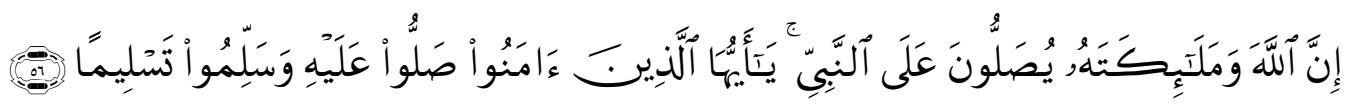

Artinya : "Sesungguhnya Allah dan malaikat-malaikat-Nya bershalawat untuk Nabi. ${ }^{6} \mathrm{Hai}$ orang-orang yang beriman, bershalawatlah kamu untuk nabi, dan ucapkanlah salam penghormatan kepadanya". ${ }^{7}$ (QS. Al Ahzab 56)

a. Sholawat sebagai pembersih dosa.

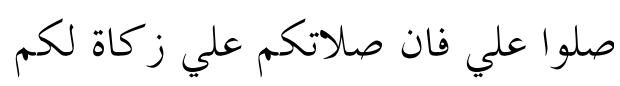

${ }^{5}$ Muhammad bin Ibrahim bin Abdullah at Tuwaijiri, Ensiklopedi Islam al Kamil, (Jakarta: Darussunnah, 2014), h. 509

${ }^{6}$ Bersholawat artinya: kalau dari Allah berarti memberi rahmat kepada hambaNya : bersholawat dari malaikat berarti memintakan ampunan, dan kalau bersholawat dari orang-orang mukmin berarti berdo'a supaya diberi rahmat oleh Allah, seperti dengan perkataan: Allahuma sholli ‘ala Muhammad (ya Allah berilah kesejahteraan atas Nabi Muhammad), maka kesejahteraan itu kembali kepada yang bersholawat sebagai do'a.

${ }^{7}$ Dengan mengucapkan perkataan seperti: Assalamu'alaika ayyuhan Nabi artinya: semoga keselamatan tercurah kepadamu Hai Nabi. Nabi sudah ada jaminan selamat, sholawat dan salam kepada Nabi adalah sebagai penghormatan, mudah-mudah sholawat ini sebagai do'a yang makbul kembali kepada yang bersholawat menjadi do'a kebaikan dan keselamatan. 
Artinya: "Bersholawatlah kamu kepadaku, karena sesungguhnya sholawatmu itu menjadi pembening dan pembersih dosa untukmu". (HR. Ahmad)

b. Sholawat sebagai jaminan mendapatkan bantuan syafa'at di hari akhirat.

Apabila kamu mendengar seorang muazzin sedang mengumandangkan azan, maka jawablah ucapan azan itu seperti yang diucapkan oleh muazzin, ${ }^{8}$ kemudian setelah azan bersholawatlah kepadaku (baca do'a seteleh mendengar azan), maka barangsiapa yang bersholawat kepadaku dengan satu sholawat, niscaya Allah bersholawat kepadanya dengan sepuluh sholawat, setelah itu mohonlah kepada Allah washilah untukku, washilah itu merupakan suatu kedudukan yang paling tinggi dan syurga, tidak dapat diperoleh melainkan oleh seorang saja dari hamba Allah, aku berharap akulah yang mendapat kedudukan itu, oleh karena itu barangsiapa yang memohonkan washilah untukku, wajiblah baginya untuk memperoleh syafa'atku. (HR. Muslim)

Inilah do'a sholawat setelah azan :

$$
\begin{aligned}
& \text { اللهم رب هذه الدعوة التامة, والصلاة القائمة ات سيدنا محمد ن الوصلية والفضيلة, والشرف } \\
& \text { والدرجةالعالية الرفيعة, وابعثه المقام الح مود ن الذي وعد ته. انك لا تخلف الميعاد. }
\end{aligned}
$$

Artinya: "Ya Allah, Yang Maha Penyempurna Permohonan, dan konsekwen dalam memberikan kesejahteraan kepada Nabi Muhammad sebagai washilah dan fadhilah serta kemuliaan dan mengangkat derjat yang tinggi, utuslah maqam yang terpuji yang telah Engkau janjikan kepadanya. Sesungguhnya Engkau tidak pernah mengingkari janji”.

c. Sholawat mengawali do'a masuk masjid.

Sabda Rasulullah SAW: apabila salah seorang diantara kamu masuk ke dalam masjid, maka hendaklah ia membaca salam kepadaku (bersholawat), sesudah itu hendaklah ia membaca do'a masuk dan keluar masjid, hadis Rasulullah SAW

$$
\text { فليقل : الذادخل احدكم المسجد فليسلم على النبي ثم اليقل : اللهم افتح لي ابواب رحتك. واذك من اذا خرج }
$$

Artinya: "Apabila salah seorang diantara kamu masuk ke dalam masjid hendaklah kamu mengucapkan salam kepada Nabi (bersholawat), sesudah itu bacalah do'a Allahhummaftahli abwaba rohmatik, (ya Allah bukakanlah pintu rahmatMu). Dan apabila keluar dari masjid bacalah Allahumma inni as aluka minfadhlik (ya Allah aku mohon kepadaMu limpahan rahmatMu)". (HR. Abu Daud)

d. Sholawat menjadi rukun dalam sholat fardhu, sholat janazah dan pada khutbah jum'at.

e. Sholawat sebagai prangko penyampai do'a, sabda Rasuullah SAW :

${ }^{8}$ Kecuali pada kalimat hayya'alashsholah \& hayya'alal falah, jawabannya lahaula wala quwwata illa billah. Dan ketika qomat, qodqomatishsholah jawabannya aqomahallu wa adamah, ketika ashsholatu khoirun min an-naum jawabnya shoddaqta wa barorta wa ana 'ala zalika min asy-syahidin 


$$
\text { ان الدعاء موقوف بين السماء والارض لا يصعد منه شيء حتى تصلي على نبيك. }
$$

Artinya: "Sesungguhnyado'a itu terhalang (berhenti) antara langit dan bumi, ia tidak akan naik barang sedikitpunjuga, sehinggaengkaubersholawatkepadaNabimu". (HR. Ar Rahawy al Jami')

f. Membaca sholawat tiap-tiap mengadakan majlis zikir, sebagaimana sabda Rasul : "Tidak duduksesuatukaum didalam suatu majlis sedangmerekamenyebutnama allah dan tidak bersholawatkepda Nabinya, melainkan merekamenderitakekurangan dan jika Allah menghendakiniscaya Allah akan mengazabmerekadanjika Allah mengehendaki niscaya akan mengampunimereka". (HR. Tumuzi dan Abu Daud) ${ }^{9}$

\section{Zikir Dalam bentuk do’a}

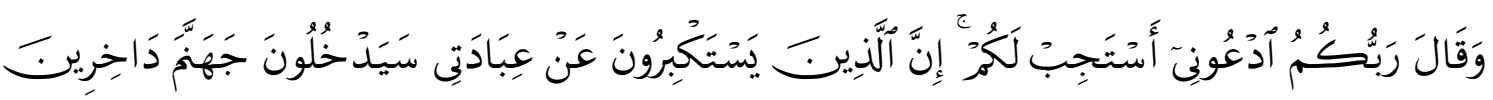

Artinya: "Dan Tuhanmu berfirman:"Berdoalahkepada-Ku, niscaya akan Kuperkenankan bagimu. Sesungguhnyaorang-orangyang menyombongkandiri dari menyembah-Ku [berdo'a kepada-Kı] akan masukneraka Jahannam dalam keadaan hina dina". (QS al- Mukmin: 60)

Dari tunjukan ayat ini Allah SWT menyuruh hambanya berdo'a, karena do'a seorang hambanya di dengar oleh Allah SWT dan barangsiapa yang enggan berdo'a kehadirat Allah, maka Allah murka kepadanya dan dicap dia sebagai orang yang sombong dan akan ditempatakan pada neraka jahannam dalam keadaan yang sangat hina.

Sabda Rasulullah SAW dari Abu Said al Khudry:

$$
\begin{aligned}
& \text { ما من مسلم يدعوا ليس بأثم ولا بقاطعة رحم الا اعطاه احدى ثلاث: }
\end{aligned}
$$

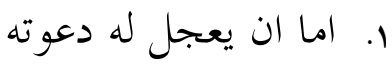

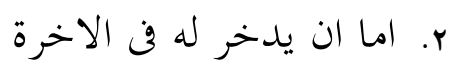

$$
\begin{aligned}
& \text { r. اما ان يدفع عنه من السوء مثلها.رواه البخاري }
\end{aligned}
$$

Artinya: "TidakseorangMuslimyangberdo'ayangbukan untukperbuatandosadan me-mutuskan kekeluargaan,kecualiAllah memberinyadari salah satu tiga kemungkinan,yaitu:

1. Menyegerakan(mengkabulkan)do'anya,

2. Permintaannya disimpankan untuk di akhirat nanti, atau

3. Disingkirkan darinya bala bencanayang semisaldenganbalasan do'anya". (HR. Bukhary)

${ }^{9}$ Mujaddidul Islam Mafa, MenyibakkedahsyatanZikir, Cet. I, (t.t.p.: Lumbung Insani, 2009), h. 69 
a. Do'a-do'a dalam al Qur'an, diantaranya: ${ }^{10}$

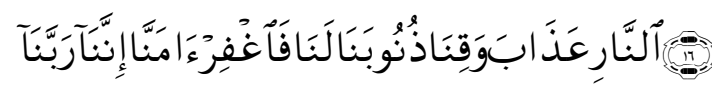

Artinya: ... Ya Tuhan kami, Sesungguhnyakami Telah beriman, Maka ampunilah segala dosa kami dan peliharalah kami dari siksa neraka,"

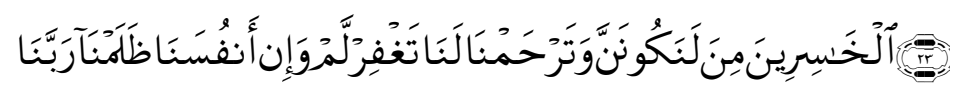

Artinya: ... "Ya Tuhan kami, kami Telahmenganiayadiri kami sendiri,danjika Engkautidak mengampunikami dan memberirahmat kepadakami, niscaya Pastilah kami termasuk orang-orangyang merugi.

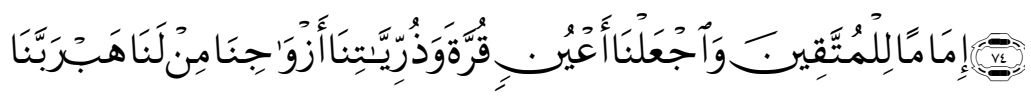

Artinya: ..."Ya Tuhan kami, anugrahkanlah kepadakami isteri-isterikami dan keturunan kami sebagaipenyenanghati (Kami), dan jadikanlah kami imam bagi orang-orangyang bertakwa.

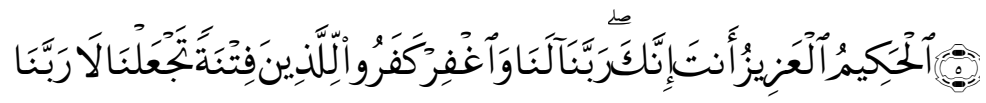

Artinya: "Ya Tuhan kami, janganlah Engkaujadikan kami (sasaran) fitnah bagi orangorang kafir. dan ampunilah kami Ya Tuhan kami. SesungguhnyaEngkaulahyang Maha Perkasa lagi Maha Bijaksana".

b. Do'a-do'a dari hadis Nabi, diantaranya Nabi berodo'a ketika ada hajatnya :

$$
\begin{aligned}
& \text { لا اله الا الله الحليم الكريع. سبحان الله رب العرش العظيم. الحمد لله رب العالمين. اسئك }
\end{aligned}
$$

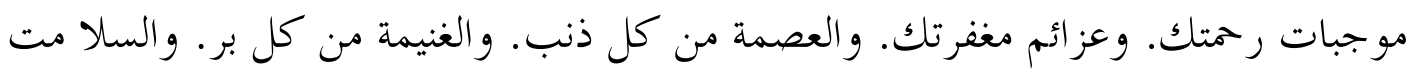

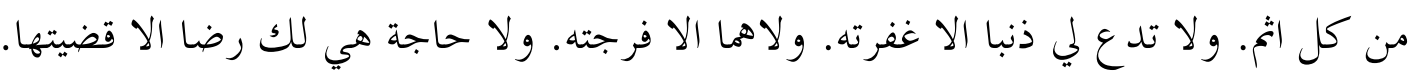

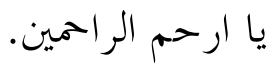

Artinya: "Tidak ada Tuhan selain Allah, yang maha bijaksana lagi Maha mulia, maha suciAllah Tuhan Arasy yang Agung,segalapuji bagi Allah Tuhan semestaalam. kepdaMu aku memohonterkabulnyasesuatuyang mewajibkanrahmatMu dan sesuatuyang mendatangkan ampunanMu, serta memperolehkeuntunganpada tiap-tiap kebaikan, dan keselamtandari tiap tiap dosa, kerenaitu janganlah Engkaubiarkan dosadari pada diriku, melainkan Engkaumengampuninyadan tidak ada suatu kepentinganmelainkanEngkau berijalan keluarsertatidak pula sesuatuhajat yang mendapatkankeridhaanMumelainkan Engkau kabulkan, wahai Tuhan yang Maha Penyayang dari semuayang Penyayang".

\footnotetext{
${ }^{10}$ Syeikh Muhammad bin Ibrahim bin Abdullah at Tuwaijiri, Ensiklopedisslamal Kamil, Darussunnah, (Jakarta: 2014), h. 569
} 
Kemudiania kemukakanhajatnya dari urusan duniaatau akhirat yangdiingininya.Sesunggrhnya itu akan ditentukan". (HR. Tirmizi, Nasa-i dan Ibnu Majah) ${ }^{11}$

\section{Zikir dalam kalimat hauqolah}

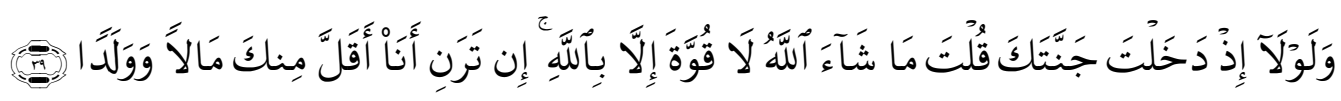

Artinya : "Dan Mengapa kamu tidak mengatakan waktu kamu memasuki kebunmu: maasyaallaah, laa quwwata illaa billaah (sungguhatas kehendakAllah semuaini terwujud, tiada kekuatan kecualidenganpertolonganAllah). sekiranya kamu anggapAku lebihsedikit darimu dalam hal harta dan keturunan". (QS. Al Kahfi: 39)

Tidak ada daya dan kekuatan melainkan dengan pertolongan Allah, maksudnya adalah kita mengakui bahwa tidak ada yang dapat memalingkan hamba dari maksiat selain dari Allah sendiri, dan tidak ada kekuatan bagi hamba untuk melaksanakan ketaatan melainkan dengan taufiqNya juga. Sabda Rasulullah SAW :

$$
\text { اربعة من كترالجنة: اخفاء الصدقة, و كتمان المصيبة, وصلة الرحم, وقول لاحول ولا قوة الا بالله }
$$

Artinya : Dari Abi Hurairah ra, katanya telah bersabda Rasulullah SAW : "Ada empat macammenjadikanzuljannah (tabungansyurga) ${ }^{12}$, yaitu: Menyembunyikansedekah,Bersabar dalam menghadapimusibah, Menyambungtali silaturrahim, Banyak berzikirdengankalimat La haula wala quwwata illa billah (tidak ada kekuatan kecualikekuatan dari Allah)". (HR. Abiddunya)

Dalam kitab Mukhtarul Ahadis oleh Sayyid Ahmad al Hasyimi tercatat bahwa zikir dengan kalimat hauqolah menjadi penawar dari kesulitan dan penyakit.

$$
\text { لا حول ولا قوة الا بالله دواء من تسعة وتسعين داء ايسرها الهم. راه ابى الدنيا }
$$

Artinya : "Tidak ada daya dan kekuatan kecualipertolonganAllah, kalimat ini merupakan penawarbagi 99 macam penyakit, yang paling ringan adalah kesusahan”. (HR. Abiddunya)

\section{Zikir dengan kalimat Basmalah}

Sejarah Islam mencatatkan Nabi Sulaiman As dengan kerajaannya yang sangat besar, ketika mengajak Ratu Balqis Ratu kerajaan Saba' untuk mengesakan Allah dalam

${ }^{11}$ Syeikh Hasan al Banna, Al-Matsurat, h. 93

${ }^{12}$ Kanzul Jannah ialah perbendaharaan syurga, makna yang dimaksud ialah pahala tabungan yang tersimpan di dalam syurga, barang siapa yang mengerjakan salah satu diantara keempat perkara itu, berarti ia menabung untuk kepentingan hari kemudiannya. 
agama tauhid, Nabi Sulaiman berkirim surat dengan isi kalimat bismillahirrohmanirrohim, sebagaimana terdapat dalam al Qur'an $:^{13}$

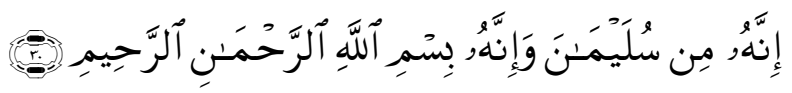

Artinya : "Sesungguhnyasurat itu dari Sulaiman dan sesungguhnya(isi)nya: "Denganmenyebut nama Allah yang Maha Pemurah lagi Maha Penyayang”. (QS. An Namal: 30)

$$
\text { كل امر ذي بال لا يبدأ فيه بسم الله الرحمن الرحيم فهو ابتر. }
$$

Artinya: "Setiap pekerjaanyang tidak dimulai denganmembacabismillahirrohmanirrohim adalah terputus (tidak berkah)". (HR. Abu Daud)

Atas nama Allah sebagai permohonan akan keberkahan pada permulaan bacaan, dengan nama Allah yang maha pengasih lagi maha penyayang, maksudnya saya membaca atau saya memulai sesuatu berdasar perintah Allah, bukan karena hawa nafsu, menyertakan nama Allah zat yang wajib adanya atau wajibul wujud.

Fadilah basmallah diantaranya :

a. Sebagai tabarruk, mencari dan mendapatkan berkah,

b. Mengusir syaitan, karena ia akan lari jika disebut nama Allah, dan jika dibaca sebanyak 21 kali, ketika akan mau tidur, insya Allah pada malam itu ia dijaga oleh Allah dari gangguan syaithan, dari kecurian dan mati mendadak.

c. Untuk meremehkan orang zalim, baca 50 kali dihadapannya, insya Allah orang zalim itu akan diremehkan oleh Allah.

\section{Zikir dalam bentuk istighfar.}

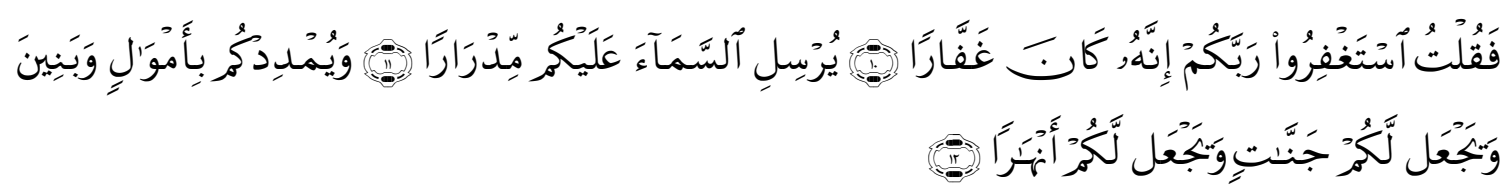

Artinya : "Maka Aku (Nabi Nuh) katakan kepadamereka:'MohonlahampunkepadaTuhanmu, -sesungguhnyadia adalah Maha PengampunNiscaya dia akan mengirimkanhujan kepadamu denganlebat, Dan membanyakkan harta dan anak-anakmu, dan mengadakanuntukmu kebun-kebundan mengadakan (pula di dalamnya) untukmu sungai-sungai". (QS. Nuh 10 $-12)^{14}$

${ }^{13}$ Hadiyah Salim, Qishashul Anbiya', (Bandung: Al Ma'arif, t.t.) h. 163.

${ }^{14}$ Dalam tafsir al-Maraghi tertulis pada masa tabi'in banyak masyarakat yang meminta fatwa dan petunjuk kepada seorang Ulama besar yaitu Hasan Bisri, diantaranya datang seorang pemuda yang mengadukan nasibnya karena mengalami paceklik, maka Hasan Basri sangat perhatian kepadanya dan menyuruh pemuda tersebut untuk berzikir dengan mendawamkan "istighfar". Pada orang yang lain juga datang mengadukan nasibnya sudah lama berumah tangga namun tidak punya anak, maka nasehat yang 
Kata istighfar berasal dari bahasa Arab yaitu ghofaro artinya menutup, jadi beristighfar berarti berusaha untuk menutup dosa-dosa yang ada, karena dosa seorang hamba itu adakalanya ditutupi, ada kalanya dihapus dan adakalanya dirobah oleh Allah SWT. Sabda Rasulullah SAW :

من لزم الاستغفر جعل الله له من كل هم فرحا ومن ضيق مخرجا ورزقه من حيث لايحتسب. Artinya : "Barangsiapa yang membiasakanistighfar, maka Allah akan membebaskannya dari kedukaan, dan memberinyajalan keluar dari kesempitannyadan memberinyarezki dari jalan yang tidak diduga-duga".(HR. Abu Daud)

Bentuk istighfar pendek:

$$
\text { استغفر الله العظيم, الذي لا اله الا هو الحي القيوم واتوب اليه }
$$

Artinya : "Aku minta ampun kepadaAllah yang maha Agung,yang tidak ada Tuhan selain Dia, maha hidup berdirisendiri, aku bertaubatkepadaNya". (HR. Muslim)

Sayyidul istighfar (penghulu dari seluruh istighfar), hadis dari Syaddad bin Aus ra, dari Nabi SAW beliau bersabda; sayyidul istighfar ialah :

$$
\begin{aligned}
& \text { اللهم انت ربي لا اله الا انت خلقتنى وانا عبدك و انا على عهدك ووعدك ماستطعت اعوذبك من }
\end{aligned}
$$

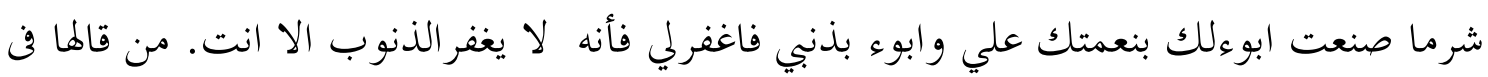

$$
\begin{aligned}
& \text { النهار موقنا بها فمات من يومه قبل ان يمسي فهو من اهل الجنة. من قالها من الليل وهو موقن بها } \\
& \text { فمات قبل ان يصبح فهو من اهل الجنة.رواه البخاري }
\end{aligned}
$$

Artinya : "Ya Allah, Engkau Tuhanku, tidak ada Tuhan selain Engkau, yang menjadikan aku, aku adalah hambaMu dan aku pun termasukdalam ketentuanMudan janji-janjiMu sedapatmungkinaku lakukakan. Aku memohonperlindunganMudari apapun perkara kejelkan yang telah aku lakukan; aku mengakuisegala nikmat yang telah Engkau berikan kepadaku dan aku juga mengakuiatas dosa-dosayangkulakakan, maka ampunilahaku, karena sesungguhnya tidak ada yang menghapuskandosa kecualiEngkau". Barangsiapa yang membacasayyidul istighfar pada waktu siang denganmeyakini apa yang diucapkannyakemudianpada siang itu juga sebelummasuk waktu soreia meninggaldunia, maka ia tercatat termasukahli syurga, danbarangsiapayangmembacanyapadawaktumalam hari denganmeyakiniapayangdiucapkannya kemudiania meninggalsebelummasuk waktu pagi maka ia tercatat termasukahi syurga". (HR. Bukhari) ${ }^{15}$

diberikan Hasan Basri kepada laki-laki itu tidak panjang-panjang, ia hanya memberi nasehat "beristighfarlah kepada Allah SWT"

${ }^{15}$ Muslich Shabir, 400 hadis Pilihan TentangAkidah, Syari'ah dan akhlak, (al Ma'arif, Bandung), h. 215 
Fadhilah (keutamaan) istighfar :

a. Mensucikan diri dari kesalahan dan menghapus dosa

b. Menawarkan hati yang gundah, karena dosa

c. Menghilangkan duka, menumbuhkan inisiatif dan mendapat rezki dari jalan yang tidak diduga.

d. Menjadikan sebab diterimanya taubat dan memperoleh husnul khotimah

e. Meruntuhkan tipu daya iblis dan menghancurkan kesesatan yang diperintahkannya

f. Mendekatkan diri kepada Allah SWT

g. Membersihkan hati dari lalai dan Melicinkan hati dari kelupaan. ${ }^{16}$

\section{Zikir dengan kalimat takbir}

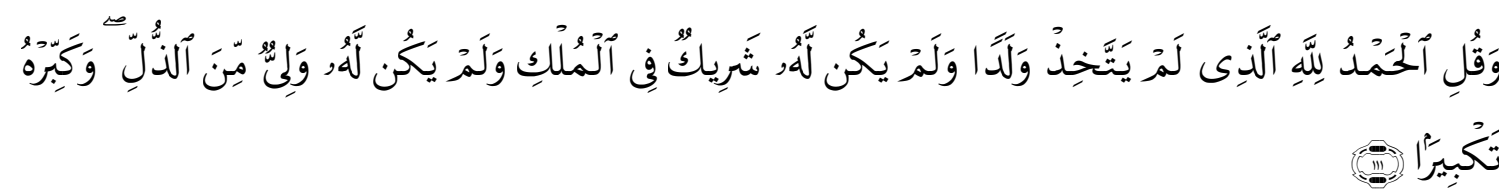

Artinya: "Dan Katakanlah: "SegalapujibagiAllahyangtidakmempunyaianak dantidakmempunyai sekutudalam kerajaan-Nya dan dia bukan pula hina yang memerlukanpenolongdan agungkanlah dia denganpengagunganyang sebesar-besarnya”.(QS. Al Israk: 111)

Allah Maha Besar atau Paling Besar dari segala yang besar, artinya kekuasaan Allah tidak terhingga besarnya meliputi seluruh alam, baik alam syahadah yang dapat dilihat kasat mata maupun alam ghoibah yang tidak bisa dilihat dan disaksikan oleh kasat mata manusia. Maka dengan bertakbir berarti kita mngakui akan kebesaran Allah SWT Tuhan yang menciptakan seluruh alam. ${ }^{17}$

Allah Maha Besar, KebesaranNya tidak dapat ditandingi, selain dari Allah itu kecil. Keutamaan Takbir, diantaranya :

a. Menjadi rukun dalam sholat fardhu 'ain dan kifayah ${ }^{18}$

b. Menjadi sebutan ketika azan dan iqomah

c. Menjadi sebutan ketika takbiran pada hari raya idul fitri dan adha.

d. Menjadi ucapan pada ketika memotong hewan dan tawaf

\section{Zikir dengan bacaan tahmid atau hamdalah}

Ucapan tahmid atau hamdalah Çáŕ̈̇̃üï ááå artinya Segala Puji Bagi Allah, segala

${ }^{16}$ Mujaddidul Islam Mafa, MenyibakkedahsyatanZikir, (Lumbung Insani, Cet. I, 2009), h. 48

${ }^{17}$ Ibid., h. 44

${ }^{18}$ Ketika takbir atul ihram wajib diucapkan dan mayoritas Ulama Fiqih memanjangkan lafzul jalalah hanya 1 alif 2 harkat, beda dengan takbir intiqol perpindahan rukun, boleh memanjangkannya dan menjaharkan (lafzul jalalah) jika diperlukan dalam perpindahan rukun untuk diketahui jamaah yang ada di belakang imam. 
bentuk puji-pujian milik dan ditujukan kepada Allah, Dialah Tuhan yang memelihara seluruh alam. Maksudnya berzikir dengan lafaz tahmid ini ialah kita menyatakan pujian dan kesyukuran kehadirat Allah Tuhan semesta alam. Kalimat tahmid ini digunakan untuk menyatakan puji dan syukur kepada Allah SWT, karena dalam segala stuasi dan kondisi apapun kepadaNya pujian tertumpu, sebagaimana untaian dalam do'a :

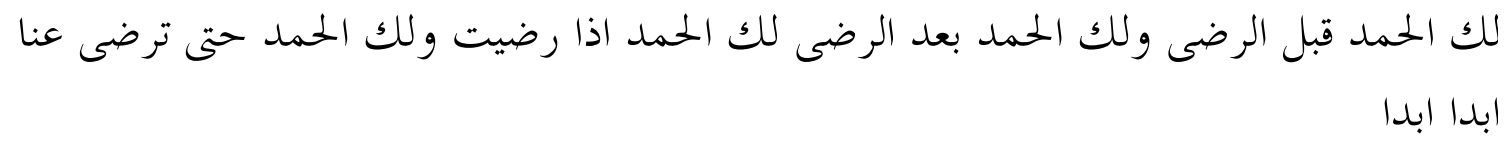

Artinya: "UntukMu segala puji sebelumEngkau ridho, bagiMu segala puji setelah Engkau ridho, bagiMu segala puji jika Engkau ridho, dan bagiMu segala puji sampai Engkau ridho dari kami untuk selama-lamanya".

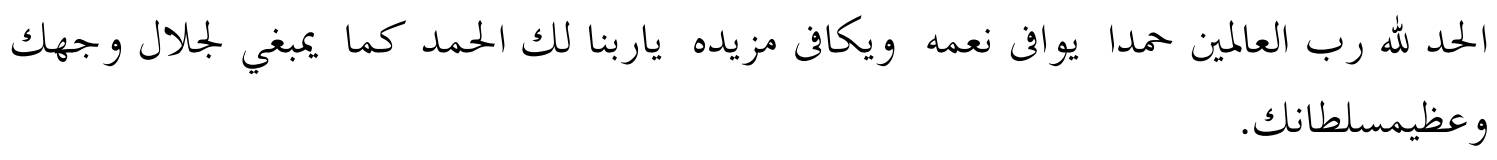

Artinya: "Segala puji bagi Allah Tuhan semesta alam, pujian untuk Allah yang telah menyempurnakannikmatNyadanmemenuhisegalakelebihanNya,ya Tuhan kami untukEngkaulah pujian yang sepantasnyakami hadapkan untuk kemuliaan wajah Engkau dan kebesaran kekuasaan Engkau".

بالله العلي العظيم لك الحمد واليك المشتكى وعليك التكلان وانت امستعان والمستغاث و لا حول و لا قوة الا

Artinya: "Ya Allah untukMu segala puji, dan kepadaMu tempat mengadu, kepadaMulah tempatmenyerahkandiri, Engkau tempatminta pertolongan,serta kepadaMutempatminta perlindungan, dan tiada daya upaya kekuatan melainkan kepada Allah yang Maha tinggi lagi Maha Mulia".

\section{Zikir dalam bentuk kalimat Hasbalah}

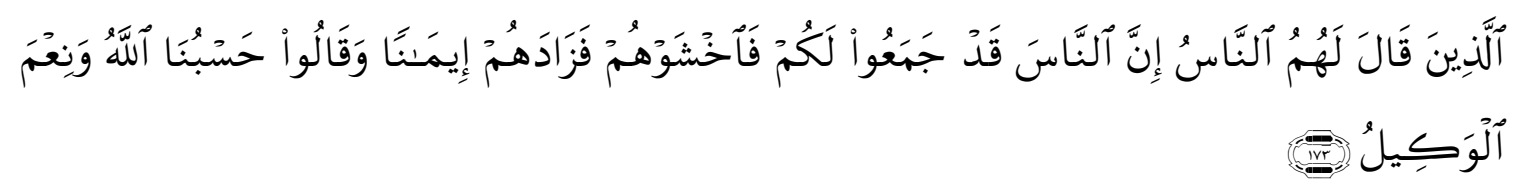

Artinya : "(yaitu) orang-orang (yang mentaati Allah dan rasul) yang kepada merekaada orang-orangyang mengatakan:"Sesungguhnyamanusia [orang Quraisy] Telahmengumpulkan pasukan untuk menyerangkamu, Karena itu takutlah kepada mereka", Maka perkataan itu menambahkeimanan merekadan merekamenjawab:"CukuplahAllah menjadipenolong kami dan Allah adalah sebaik-baikPelindung”.(QS. Ali Imran 173)

Kalimat "hasbalah" ialah : "Hasbiyalluhuwani'mal wakil", atau "HasbunallahuWani'mal 
wakil". Allah SWT telah cukup bagiku, aku tidak perlu kepada selainNya; dan Dialah sebaikbaik penjaga yang menjaga segala kemaslahatan dan kemanfaatan. Maksudnya kita mengaku sekaligus meyakini dengan seyakin-yakinnya bahwa tempat berpegang dan bergantung seorang hamba hanya kepada Allah saja. Dan bahwa berpegang kepada Allah itu sudah mencukupi dan mumpuni, tidak memerlukan kepada sesuatu pegangan yang lain. ${ }^{19}$

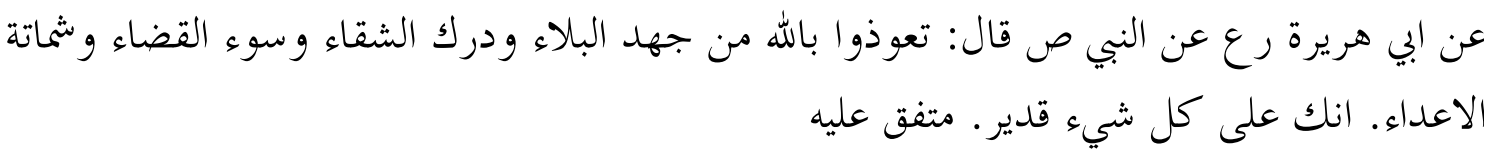

Artinya : dari Abu Hurairah ra, dari Nabi saw, beliaubersabda:berlindunglahkalian kepada Allah dari beratnyacobaan, tertimpakesulitan,jeleknyatakdir dan cemoohanmusuh, sesungguhnya Engkau Maha Kuasa menentukansesuatu.HR. Bukhari dan Muslim

Rasulullah SAW menyuruh ummatnya mohon perlindungan dari empat macam :

1. Jahdil bala' (beratnya cobaan)

Semua manusia yang diciptakan Allah mendapat cobaan dalam menempuh hidup dan kehidupannya, Cuma ada yang ringan ada yang berat, ada yang terus menerus ada yang sifatnya sementara, ada yang diketahuinya ada yang tidak diketahuinya. Sabda Rasulullah SAW :

من يردالله به خيرا يصب منه.

Artinya : "Barangsiapa yang dikehendakiAllah menjadikan hambanya menjadiorang yang baik, maka terlebihdahulu diujinya dengansuatu cobaan”. (HR. Muslim)

Kalau seseorang mendapat musibah, maka zikirlah dengan kalimat istirja': innalillahi wainna ilaihi roji'un, allahummakjurnifi mushibatiwakhluflikhoironminha. "Sesungguhnya kita milik Allah dan sesungguhnya kita kepadaNya semua kembali.Ya Allah damping aku pada mushibah ini dan berilah jalan keluar yang lebih baik daripadanya. Insya Allah, Allah akan memberi ketenangan kepadanya dan mengganti mushibahnya dengan keadaan yang lebih baik dari yang di derita atau yang disedihkannya".

2. Darqisysyiqo'(ditimpa kesulitan)

Menjalani hidup dan kehidupan ini tidak senantiasa mulus, adakalanya mengalami kesulitan, justru itu dalam ajaran Islam diajarkan apabila ditimpa kesulitan janganlah ia berputus asa dan usahakan:

a. Ikhtiar usaha melepaskan diri dari kesulitan itu,

b. Berdo'a dengan tulus mengharap kepada Allah SWT yang maha kaya dan pemurah

c. Bertawakkal kepada Allah

${ }^{19}$ Mujaddidul Islam Mafa, MenyibakKedahsyatanZikir, ( Lumbung Insani, Cet. I, 2009), h. 45 
3. Suuil Qodo' (jeleknya takdir)

Seorang Muslim wajib percaya dan mengimani adanya qododan qodar, qodo ialah keputusan Allah sejak zaman azali, sedangkan taqdir ialah keputusan Allah setelah hambaNya melakukan dan berusaha dalam menjalani kehidupannya. Justru itu Rasulullah menyuruh berdo'a agar taqdir keputusan atau vonis dari Allah adalah mendapat hikmah kebaikan dari hasil usaha hambaNya, jangan mendapat taqdir yang jelek, kalau taqdir tidak bisa berobah tentu Rasul tidak menyuruh ummatnya untuk bermohon agar terhindar dari takdir yang jelek.

4. Syamatah al-a'da' (cemoohan musuh)

Musuh kaum Muslimin yang beriman bukan hanya orang orang kafir, namun syaithan la'natullah menyelusup dalam teorinya dalam berbagai hal. Justru itu berjalanlah diatas jalan yang lurus (benar), kalau kita sudah direl yang benar, maka istiqomahlah, walaupun mendapat cemoohan dan gangguan dari musuh-musuh Allah.

\section{Zikir dengan Ismul A'zom}

Zikir dengan ismul a'zom ialah menzikirkan nama-nama Allah yang agung, seperti menzikirkan asma ul husna, firman Allah SWT :

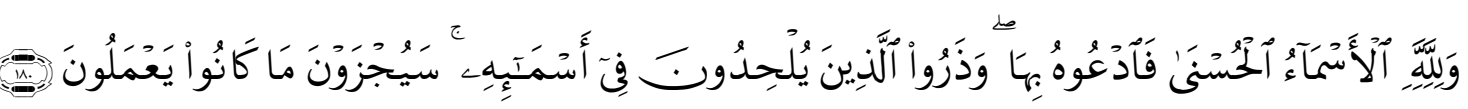

Artinya : "Hanya milik Allah Asmaa-ul husna, ${ }^{20}$ Maka bermohonlahkepada-Nya dengan menyebutasmaa-ul husnaitu dan tinggalkanlahorang-orangyang menyimpangdari kebenaran dalam (menyebut)nama-nama-Nya. ${ }^{21}$ Nanti merekaakan mendapatbalasan terhadapapa yang telah merekakerjakan". (QS. Al-A'raf: 180)

Sabda Rasulullah SAW :

$$
\text { ان لله تسعة وتسعين اسما مائة الا واحدا من احصاها دخل الجنة. رواه البخاري }
$$

Artinya : "SesungguhnyaAllah mempunyai99 nama, yaitu seratuskurang satu, siapa yang menghitungnyamasuk syurga". (HR. Bukhari) ${ }^{22}$

$$
\text { لله تسعة وتسعين اسما من حفظها دخل الجنة وان الله تريحب الوتر. رواه مسلم }
$$

${ }^{20}$ Maksudnya: nama-nama Allah yang baik/Agung, yang sesuai dengan sifat-sifat Allah.

${ }^{21}$ Maksudnya: janganlah dihiraukan orang-orang yang menyembah Allah dengan nama-nama yang tidak sesuai dengan sifat-sifat dan keagungan Allah, atau dengan memakai asmaa-ul husna, tetapi dengan maksud menodai nama Allah atau mempergunakan asmaa-ul husna untuk nama-nama selain Allah.

${ }^{22}$ Imam Bukhari,Shohih Bukhari, Terj. H.Zainuddin Hamidy et.all Jld-IV, (Jakarta: Widjaya, 1999), h. 188 
Artinya : "Allah mempunyai99 nama, siapa yang menghafalnyamasuksyurga. Dan sesungguhnya Allah Maha Tunggal, menyukaiyang tunggal". (HR. Muslim)

Dalam kitab al-Azkar disebutkan maksud dari dapat menghitung atau menghapalnya ialah mengerti maknanya, mempercayainya dan mengamalkannya. (lihat al-Azkar oleh Imam Nawawy, hal. 306)

Diantara zikir asmaul husna ialah :

$$
\text { الرحمن - يارحمن -- يارحمن ارجو رحتك }
$$

"Ya Allah, yang Maha Pengasih, aku mengharapkasih sayangMu".

Barangsiapa yang mengucapkan "ya rohman" sebanyak 100 kali setiap selesai sholat fardhu, maka dengan izin Allah akan hilanglah sifat lalai dan lupa dalam dirinya.

$$
\text { الرحيم -- يارحيم -- يارحيم ارحمني }
$$

"Ya Allah..! yang Maha Penyayang, kasihi dan sayangilah aku".

Jika asma Allah ini dibaca setiap hari 100 kali setelah sholat fardhu, maka orang yang membacanya akan dilindungi, dan seluruh makhluk akan mengasihinya. ${ }^{23}$

\section{E. Bentuk zikir bil Qolbi}

1. Zikir hati dengan taubat

2. Roja' yaitu hanya berharap kepada Allah

3. Insyaf, sadar akan kelemahan dan kekurangan diri sendiri

4. Khauf, yaitu selalu merasa takut akan siksa atau azab sebagai sanksi yang diberikan kepada orang orang yang melanggar perintahNya.

\section{F. Bentuk zikir bil Jawarih}

Zikir dengan jawarih ialah merealisasikan gerak anggota badan dengan suatu aktivitas yang mengandung produktifitas, yaitu tenggelam dalam ketaatan tujuh anggota jawarih:

1. Zikir mata dengan menangis,

2. Zikir telinga dengan mendengar yang baik-baik,

3. Zikir lidah dengan memuji Allah,

4. Zikir tangan dengan memberi sedekah,

5. Zikir badan dengan menunaikan kewajiban

\footnotetext{
${ }^{23}$ M. Hermawansyah, Membuka Rahasia Manfaat Zikir Asmaul Husna Berdasarkan al Qur'an dan As Sunnah, (Kunci Iman: Jakarta, 2015), h. 7.
} 
6. Zikir hati dengan takut dan berharap, dan

7. Zikir roh dengan penyerahan diri kepada Allah dan rela. ${ }^{24}$

\section{G. Fungsi Zikir}

Imam Ibnul Qoyyim al Jauziyyah di dalam kitabnya al Waabilus Syayyib dan pada kitab Rafi'ul kalimat at Tayyib menerangkan ada tujuh fugsi zikir, yaitu :

1. Zikir dapat mengusir, mengalahkan dan menghinakan syaitan,

2. Orang yang berzikir Allah yang Maha Rahman akan rela kepadanya,

3. Zikir bisa menyebabkan hati menjadi gembira, berbahagia dan tentram, firman Allah pada surah Ar Ra'du ayat 28 :

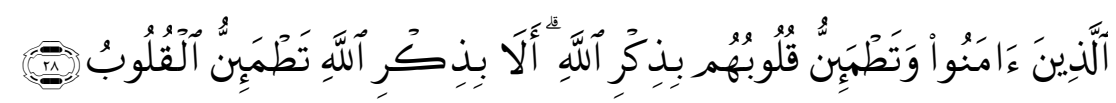

Artinya: (yaitu) orang-orangyang beriman dan hati merekamanjadi tenteramdengan mengingatAllah. Ingatlah, Hanya denganmengingatiAllah-lah hati menjaditenteram.

4. Dengan zikir, manusia akan dipermudah Allah jalan rezekinya,

5. Dengan berzikir, bisa akan terbuka baginya pintu pintu yang agung, yaitu pintu pintu pengampunan

6. Dengan memperbanyak zikir bisa menyelamatkan diri dari siksa api neraka

7. Zikir merupakan ibadah yang paling ringan. ${ }^{25}$

\section{H. Kesimpulan dan Penutup}

Zikir adalah mengingat Allah SWT bisa dalam bentuk lisan, atau perbuatan hati untuk ingat kepadaNya. Ada tiga bentuk zikir harian pada realisasinya dalam kehidupan seorang Muslim, yaitu : zikir secara lisan, zikir dalam hati (qolb) dan zikir pada amal perbuatan (jawarih). Zikir-zikir ini berfungsi untuk menghidupkan hati seseorang sehingga memancarkan cahaya yang terang benderang dan asyik dalam ibadah sehari-hari yang membawa dirinya sendiri dan orang lain dapat bergerak mengikutinya. Dalam fungsi yang lain dapat mengurangi maksiyat karena kegiatan teralih pada fokus kegiatan zikir (komunikasi sakral) antara seorang makhluk kepada Khaliqnya.

${ }^{24}$ A. Fuad Said, Hakekat Tarikat Naqsyabandiah, (Jakarta: Pustaka al Husna Baru, 2005), h. 58.

${ }^{25}$ Muqorrobin Misbah, Khasiat dan Faedah Zikir, Wirid dan Do'a, (CV. Gunung Mas, Pekalongan, 1997), h. 14 


\section{DAFTAR PUSTAKA}

Al Qur'an al Karim,

Aliyah Abidin, al Luju' Ila Allah Ad'iyyatunWa Azkarun Min Al Qur'an Wa Assunnah, Terj. Abdurrahman Wahyudi, MengungkapDimensi Ibadah Zikir dan Do'a Berdasarkan al Qur'an dan Sunnah, (Semarang: Pustaka Nuun, 2009)

Thaha Abdullah Afifi, Isyrina Miah Miftahul Jannah, 120 Kunci Surga, (Jakarta: Gema Insani Press, 1994)

Mujaddidul Islam Mafa, MenyibakkedahsyatanZikir, Cet. I (t.t.p.: Lumbung Insani, 2009)

Muhammad bin Ibrahim bin Abdullah at Tuwaijiri, EnsiklopediIslam al Kamil, (Jakarta: Darussunnah, 2014)

Ahmad bin Hajar al Haitami, Irsyad al Ibad fi Sabili ar Rasyad, Terj. Salim Bahreisj, Darussaggaf, (Surabaya: Alawy, t.t)

Hadiyah Salim, QishashulAnbiya', (Bandung: Al Ma'arif, 2009)

Muslich Shabir, 400 hadis Pilihan TentangAkidah, Syari'ah dan akhlak, Bandung: Al Ma'arif, 1988)

Imam Bukhari, Shohih Bukhari, Terj. H.Zainuddin Hamidy et.all Jld-IV, (Jakarta: Widjaya, 1998)

M. Hermawansyah, MembukaRahasia Manfaat Zikir AsmaulHusna Berdasarkan al Qur'an dan As Sunnah, (Jakarta: Kunci Iman, 2015)

Muqorrobin Misbah, Khasiat dan Faedah Zikir, Wirid dan Do'a, (Pekalongan: Gunung Mas, 1997)

A. Fuad Said, Hakekat Tarikat Naqsyabandiah, (Jakarta: Pustaka al Husna Baru, 2005)

Mahmud Yunus, Kamus Arab Indonesia (Jakarta: Hida Karya Agung, 1990) 